\title{
Study on pore and fracture evolution characteristics of oil shale pyrolysed by high-temperature water vapour
}

\author{
Jing Zhao ${ }^{(\mathrm{a}, \mathrm{b}) *}$, Lusheng Yang $^{(\mathrm{c})}$, Dong Yang $^{(\mathrm{a}, \mathrm{b})}$, Zhiqin $\mathrm{Kang}^{(\mathrm{a}, \mathrm{b})}$, \\ Lei Wang ${ }^{(a, b)}$
}

Received 28 July 2021, accepted 25 January 2022, available online 10 March 2022

(a) Key Laboratory of In-situ Property Improving Mining of Ministry of Education, Taiyuan University of Technology, Taiyuan 030024, China

(b) The In-situ Steam Injection Branch of State Center for Research and Development of Oil Shale Exploitation, Taiyuan University of Technology, Taiyuan 030024, China

(c) Shanxi Institute of Energy, Yuci 030600, China

\begin{abstract}
In this study, a self-designed test system for injecting water vapour was used to pyrolyse oil shale from Barkol, Xinjiang, China. The internal structure of oil shale samples after water vapour pyrolysis at different temperatures was characterised using micro-computed tomography (micro$C T)$. The results showed that under the action of high-temperature water vapour, oil shale underwent evident thermal cracking and pyrolysis, and the porosity increased from $0.08 \%$ of the original state to $16.73 \%$ at $550{ }^{\circ} \mathrm{C}$. At $300{ }^{\circ} \mathrm{C}$, the maximum pore group was distributed along the bedding plane due to the influence of thermal cracking, and the equivalent diameter was 1201.73 $\mu \mathrm{m}$. When the water vapour temperature increased from $300^{\circ} \mathrm{C}$ to $400{ }^{\circ} \mathrm{C}$, the organic matter at a low boiling point in oil shale began to pyrolyse, forming several pores. These pores were gradually connected with adjacent fractures. The pores with an equivalent diameter of approximately100-500 $\mu \mathrm{m}$ in oil shale accounted for $>60 \%$ of the total pore volume. The maximum pore cluster expanded perpendicular to the bedding plane, but there was still no effective seepage channel. With an increase in the water vapour temperature, the largescale pyrolysis of organic matter began and the pores and fractures in oil shale were continuously generated and gradually connected; at $450^{\circ} \mathrm{C}$, the seepage channel connecting the entire digital core area began to form. At $550^{\circ} \mathrm{C}$, the equivalent diameter of the maximum pore group reached $5756.72 \mu \mathrm{m}$, accounting for $69.65 \%$ of the total pore volume.
\end{abstract}

Keywords: water vapour, Chinese Barkol oil shale, pore structure, microcomputed tomography, temperature.

\footnotetext{
* Corresponding author: e-mail zhaojing19860207@163.com

(C) 2022 Authors. This is an Open Access article distributed under the terms and conditions of the Creative Commons Attribution 4.0 International License CC BY 4.0 (http://creativecommons.org/licenses/by/4.0).
} 


\section{Introduction}

The use of conventional oil and gas resources, such as coal, oil and natural gas, occupies a dominant position in the rapid development of the world economy [1]. At the same time, the amount of resources cannot meet the needs of industrial production. Oil shale is a fine, dense and layered sedimentary rock containing inorganic mineral skeletons (carbonate, silicate, pyrite and other minerals) and organic matter (bitumen and kerogen) [2-4]. The latter mainly comprises solid kerogen. After pyrolysis, kerogen is converted into shale oil, gas and solid residues; shale oil can be processed to produce various oils [5-7]. China is rich in oil shale resources, ranking second in the world. The amount of oil shale resources is approximately 978 billion tonnes, which is converted to 61 billion tonnes of shale oil resources [8,9]. Oil shale can be used as a supplementary and alternative energy source for oil, and its development and use have attracted extensive attention [10].

The development technologies of oil shale mainly include in-situ conversion methods and surface retorting. Compared with the surfaceretorting technology, the in-situ conversion methods offer the advantage of not requiring any mining and constructing large-scale tail gas treatment facilities. These conversion methods enable developing deep and high-thickness oil shale resources with less land occupation and environmental pollution $[11,12]$. Presently, there exist more than ten such methods. According to heat source, they can be divided into conduction, convection and radiation heating [13]. Among these heating methods, convective heating outstands for high heat conduction, fast heating and high recovery rates [14, 15]. During an in situ heat injection exploitation of oil shale, with the pyrolysis of organic matter and the thermal fracture of the inorganic mineral skeleton, there takes place a constant evolution of the pore structure of oil shale. The development degree of pores and fractures determines the migration and output of oil and gas products, so it is essential to study the pore and fracture structures during pyrolysis.

Many scholars have recently studied the original state of oil shale and evolution characteristics of pore structure after pyrolysis. According to the literature, the porosity and pore connectivity of oil shale increase after pyrolysis. Lei et al. [16] used various testing methods to characterise the pore structure of oil shale. The results showed that the pyrolysis caused the porosity of oil shale to increase markedly and the sizes of the pores change from main nano- to co-developed micro-nano-pores. Using a similar approach of threedimensional (3D) X-ray tomography, Saif et al. [17] revealed that a significant increase in porosity occurred at a temperature of $390{ }^{\circ} \mathrm{C}$ (approximately $20-25 \%$ ); further heating mainly caused the growth of the pore connectivity. Zhao et al. [18] quantitatively analysed the pore structure of oil shale samples from the Shahejie formation of the Dongying depression by using focused ion beam scanning electron microspy (FIB-SEM) and digital rock technology. 
Using Maoming oil shale samples in Guangdong Province, Li et al. [19] performed a nuclear magnetic resonance (NMR) test of oil shale samples heated to different temperatures under simulated in situ stress state. The results showed that the porosity increased gradually in the range of $250-350^{\circ} \mathrm{C}$, decreased slightly in the range of $350-400^{\circ} \mathrm{C}$, and increased significantly above $400{ }^{\circ} \mathrm{C}$. Yang et al. [20] used the mercury intrusion method to characterise the pore structure of Chinese Daqing oil shale after high-temperature pyrolysis. The results showed that the porosity of the oil shale sample after high-temperature pyrolysis at $600{ }^{\circ} \mathrm{C}$ increased by $34.6 \%$ and the volume of meso-pores gradually increased. In previous studies, the oil shale heating method used has been mainly conduction heating; research on convective heating has been relatively modest. Mozaffari et al. [21] pyrolysed a sample of Estonian kukersite oil shale using a Fischer assay method under $\mathrm{N}_{2}, \mathrm{~N}_{2} /$ steam, $\mathrm{CO}_{2}$ and $\mathrm{CO}_{2} /$ steam environments. The researchers determined that steam increased the liquid and gaseous yields and caused a more significant weight loss in oil shale. Yang et al. [22] studied the effect of heat injection temperature on the quality of oil and gas products; the results showed that the hydrogen content increased, whereas the hetero-atomic compound content was low in shale oil. Mozaffari et al. [21] and Yang et al. [22] demonstrated the advantages of in situ steam injection in oil shale mining. In the water vapour injection pyrolysis of oil shale, water vapour plays the role of a heat transfer medium; it reacts with organic matter, resulting in the evolution process of meso-structure complexity in the rock mass. Based on this, in the present study, oil shale samples were obtained at different pyrolysis temperatures using a self-designed test system for injecting water vapour to pyrolyse oil shale. The micro-computed tomography (microCT) scanning of oil shale samples was performed after water vapour pyrolysis at different temperatures. The influence of high-temperature water vapour on the oil shale's internal pore and fracture structures was studied at the micron scale.

\section{Materials and methods}

\subsection{Materials}

Samples for the study were obtained from the oil shale bearing strata of the Lower Jurassic Badaowan Formation in the North Shitanyao open pit in the Dachanggou Basin, Barkol County, Xinjiang, China. There are many oil shale layers in the area; the average oil yield of oil shale in the entire mining area is $6.52 \%$. The reserves of medium quality ores with oil yield above $5 \%$ are 46793.34 million tonnes, while the reserves of shale oil make 3124.36 million tons [23]. The Badaowan Formation oil shale has high organic matter abundance and hydrocarbon-generating potential and contains type $\mathrm{I}_{\text {and }} \mathrm{II}_{1}$ organic matter [24]. 
All samples were fresh. Table 1 presents the results of the industry analysis and low-temperature retorting of the Barkol oil shale samples.

Table. 1. Proximate and Fischer assay analyses of oil shale

\begin{tabular}{|l|c|l|c|}
\hline \multicolumn{2}{|c|}{ Proximate analysis, \% } & \multicolumn{2}{c|}{ Fischer assay analysis, \% } \\
\hline Moisture $\left(\mathrm{M}_{\mathrm{ad}}\right)$ & 1.42 & Water yield $\left(\right.$ Water $\left._{\mathrm{ad}}\right)$ & 3.88 \\
Ash $\left(\mathrm{A}_{\mathrm{d}}\right)$ & 72.33 & Residue $\left(\mathrm{CR}_{\mathrm{ad}}\right)$ & 83.12 \\
Volatile matter $\left(\mathrm{V}_{\mathrm{d}}\right)$ & 21.44 & Oil yield $\left(\mathrm{Tar}_{\mathrm{ad}}\right)$ & 8.32 \\
Fixed carbon $\left(\mathrm{FC}_{\mathrm{d}}\right)$ & 6.23 & Gas + loss & 4.68 \\
\hline
\end{tabular}

\subsection{Methods}

2.2.1. Experiments on oil shale pyrolysis by water vapour injection

Oil shale samples were pyrolysed by the test system for injecting water vapour. The test system comprises a steam generator, a temperature controller, a high-temperature reactor and a measuring instrument (Fig. 1). The steam generator's steam is $120{ }^{\circ} \mathrm{C}$, and the water vapour enters the temperature controller through a high-temperature resistant pipe to be heated and then enters the high-temperature reactor. The temperature sensor is installed inside the high-temperature reactor. The measuring instrument is connected with the temperature sensor. The water vapour temperature entering the reactor can be monitored in real time.

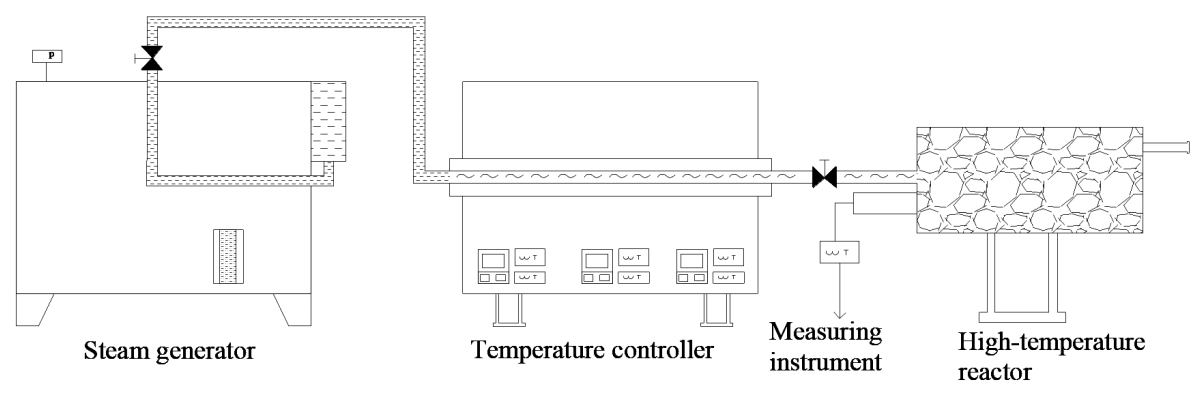

Fig. 1. Test system for oil shale pyrolysis with water vapour injection. 
The specific process of oil shale sample pyrolysis experiment was carried out as follows. The samples were placed in the high-temperature reactor to make their bedding directions roughly consistent with the water vapour injection direction. The steam generator was started to produce water vapour, and the temperature controller was set to start heating. After secondary heating, the water vapour entered the high-temperature reactor, and the oil shale samples were heated and pyrolysed. Different pyrolysis temperature points were set according to the temperature measured by the temperature sensor installed in the high-temperature reactor. When water vapour entering the high-temperature reactor reached the target temperature, the oil shale samples were pyrolysed at that temperature for $2 \mathrm{~h}$.

After pyrolysis, the temperature controller programme was set to slow down the water vapour temperature. When the temperature of the water vapour entering the high-temperature reactor was below $100{ }^{\circ} \mathrm{C}$, the temperature controller and the steam generator were shut down. The samples were slowly cooled to room temperature in the high-temperature reactor and removed. Oil shale samples after the action of water vapour at different temperatures were obtained.

\subsubsection{Thermogravimetric experiments}

A sensitive thermogravimetric (TG) analyser NETZSCH STA-449-F5S (Bavaria, Germany) was employed to simultaneously measure the TG and derivative TG (DTG) curves. The oil shale samples were ground to less than $0.2 \mathrm{~mm}$, and the mass of the oil shale sample was $20 \mathrm{mg}$. The temperature was ramped to $800{ }^{\circ} \mathrm{C}$ at a heating rate of $5^{\circ} \mathrm{C} / \mathrm{min}$ under nitrogen atmosphere; the flow rate of nitrogen was $20 \mathrm{~mL} / \mathrm{min}$.

\subsubsection{Micro-computed tomography experiments}

After the pyrolysis experiment was completed, the pore structure of the oil shale samples was characterised using a micro-CT scanning experimental system. The experimental samples were cylinders of $\varnothing 25 \times 50 \mathrm{~mm}$ (Fig. 2). In this experiment, the current value was $100 \mu \mathrm{A}$, the voltage value was $150 \mathrm{kV}$, and the size of a single pixel was $9.5 \mu \mathrm{m}$. A series of grey images could be obtained after scanning, and 3D digital cores could be obtained via the 3D reconstruction of grey image data.

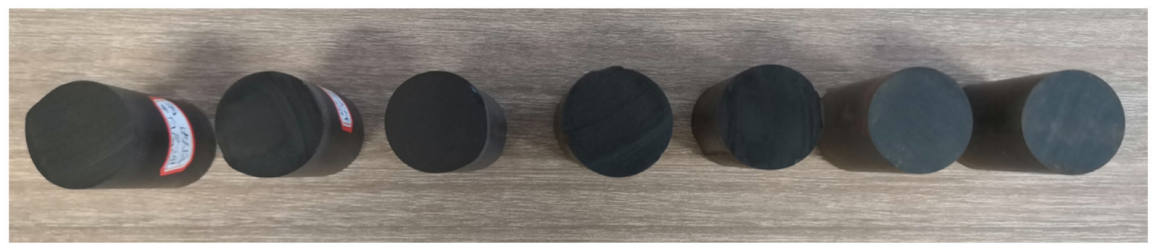

Fig. 2. Oil shale samples (size: $\varnothing 25 \times 50 \mathrm{~mm}$ ). 


\section{Results and discussion}

\subsection{Thermogravimetry and derivative thermogravimetry results of oil shale}

Figure 3 depicts the TG and DTG curves of the oil shale samples in the original state. The TG curve reflects the process of sample weight changing with temperature, whereas the DTG curve shows the rate of weight change.

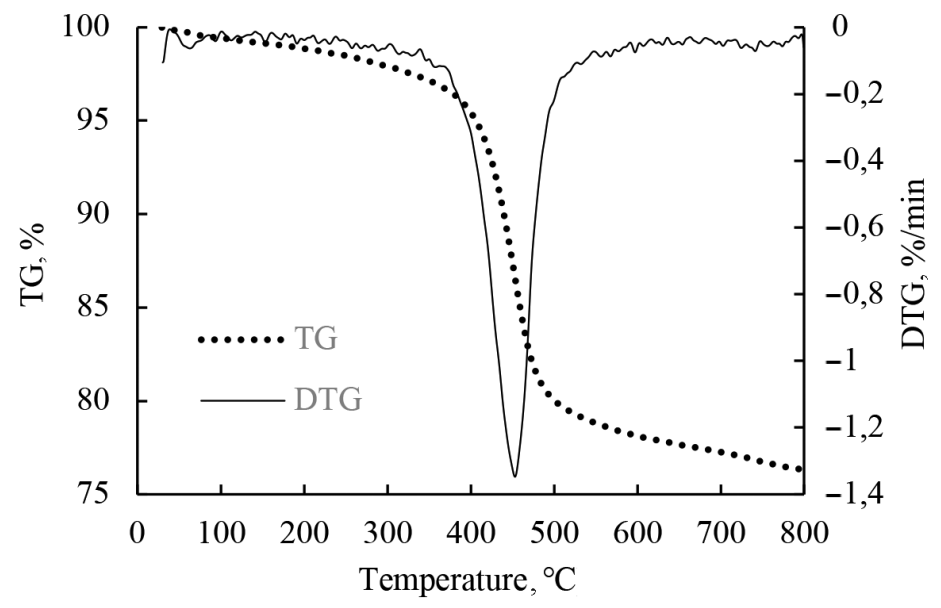

Fig. 3. TG and DTG curves of the oil shale sample.

Figure 3 displays that the weight loss during pyrolysis of Barkol oil shale can be broadly divided into the following three stages:

(1) $25^{\circ} \mathrm{C}-300{ }^{\circ} \mathrm{C}$. At this stage, the weight loss rate was relatively slow, and the DTG curve showed a small peak near $100{ }^{\circ} \mathrm{C}$, mainly due to the evaporation of adsorbed water inside the oil shale sample; the weight loss was $0.59 \%$. With an increase in temperature, the interlayer water of clay minerals in oil shale began to release, but the reaction was not apparent. In this stage, the weight loss of oil shale was $2.09 \%$, which was low.

(2) $300{ }^{\circ} \mathrm{C}-600^{\circ} \mathrm{C}$. There was no decomposition reaction of kerogen in the temperature range of $300{ }^{\circ} \mathrm{C}-350{ }^{\circ} \mathrm{C}$. Changes in the kerogen structure and volatilisation of a small amount of bitumen components with a low boiling point occurred. The weight loss at this stage was only $0.76 \%$. In the temperature range of $350{ }^{\circ} \mathrm{C}-550{ }^{\circ} \mathrm{C}$, the weight loss rate increased significantly and a prominent peak appeared in the DTG curve; the weight loss was $18.33 \%$, accounting for $77.47 \%$ of the total weight loss. This temperature range was the main weight loss stage of pyrolysis. The kerogen in oil shale was pyrolysed to generate shale oil, gas and residues. In the temperature range of $550{ }^{\circ} \mathrm{C}-600^{\circ} \mathrm{C}$, the pyrolysis reaction rate of organic matter in oil shale slowed down; the weight loss of oil shale was $0.71 \%$. 
(3) $600{ }^{\circ} \mathrm{C}-800{ }^{\circ} \mathrm{C}$. When the temperature exceeded $600{ }^{\circ} \mathrm{C}$, the reaction in oil shale was dominated by the decomposition of carbonate minerals; the weight loss at this stage was $3.90 \%$.

The TG and DTG curves in Figure 3 show that the peak temperature of pyrolysis was $458{ }^{\circ} \mathrm{C}$, and the temperature range of pyrolysis was $300{ }^{\circ} \mathrm{C}-$ $550^{\circ} \mathrm{C}$. Therefore, the water vapour temperatures selected in this study were $300{ }^{\circ} \mathrm{C}, 350{ }^{\circ} \mathrm{C}, 400{ }^{\circ} \mathrm{C}, 450{ }^{\circ} \mathrm{C}, 500{ }^{\circ} \mathrm{C}$ and $550{ }^{\circ} \mathrm{C}$.

\subsection{Evolution of the structure of oil shale under the action of high- temperature water vapour}

\subsubsection{Pore and fracture distributions of oil shale at different temperatures}

Figure 4 shows the CT grey slices of oil shale samples after the action of water vapour at different temperatures. The colour changed from black to white in the CT slices, which indicated the difference in rock density. The greater the material density was, the higher the brightness of the image was, and the minerals were white. The density of pores and fractures is the smallest, showing black. Organic matter is grey. A 3D digital core with a size of $1000 \times 1000 \times 1000$ pixels (the actual width of each pixel was $9.5 \mu \mathrm{m}$ ) was selected to analyse pore connectivity inside the oil shale samples. A 3D volume-rendering oil shale digital core can be obtained by threshold segmentation (Fig. 5), where the colour part is pore and fracture space.

Figure 5 demonstrates that water vapour had a significant impact on the structure and development degree of pores and fractures in oil shale. With an increase in water vapour temperature, the development of pores and fractures

(a)

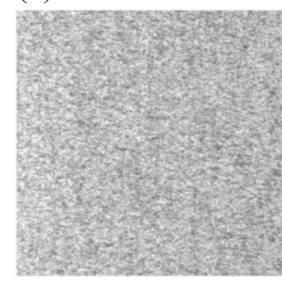

(d)

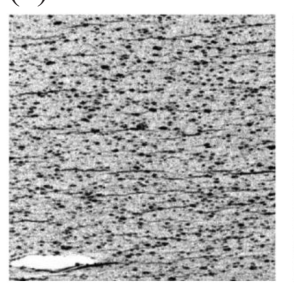

(b)

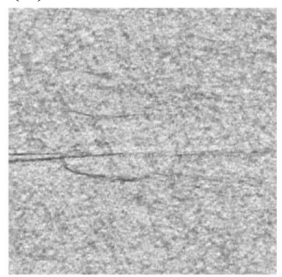

(f)

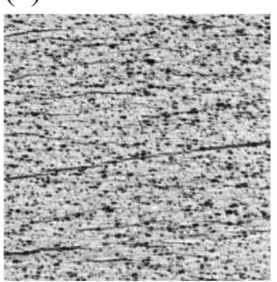

(c)

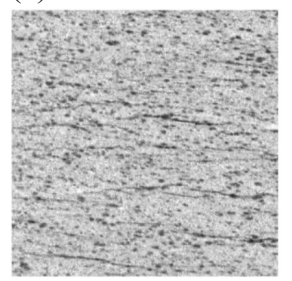

(g)

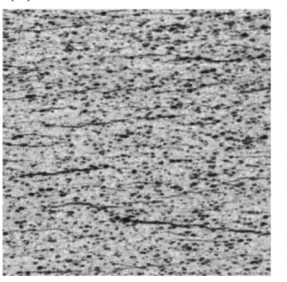

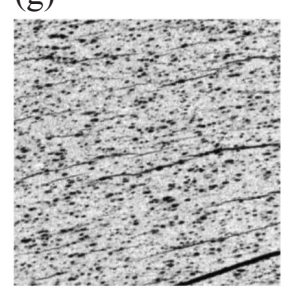

Fig. 4. CT grey slices of oil shale samples $(1000 \times 1000$ pixels $)$ at different temperatures: (a) original sample $\left(25^{\circ} \mathrm{C}\right.$ ); (b) $300{ }^{\circ} \mathrm{C}$; (c) $350{ }^{\circ} \mathrm{C}$; (d) $400{ }^{\circ} \mathrm{C}$; (e) $450{ }^{\circ} \mathrm{C}$; (f) $500{ }^{\circ} \mathrm{C}$; (g) $550{ }^{\circ} \mathrm{C}$. 
(b)

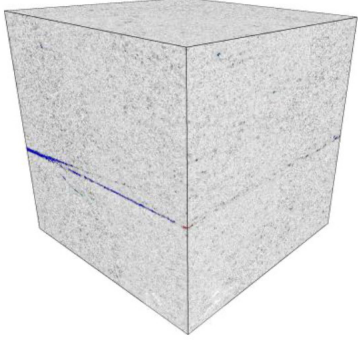

(e)

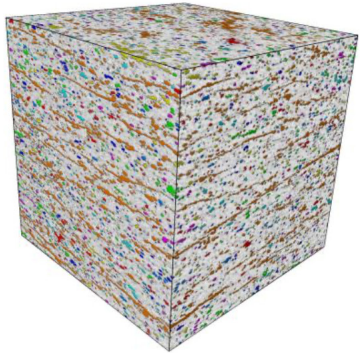

(a)

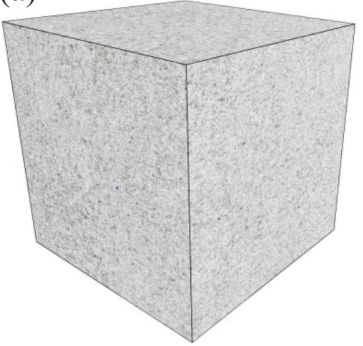

(c)

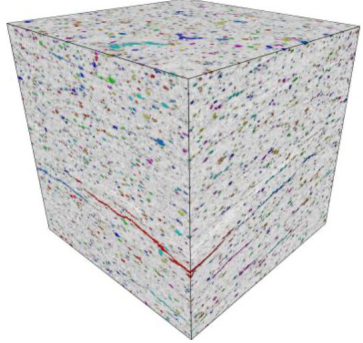

(f)

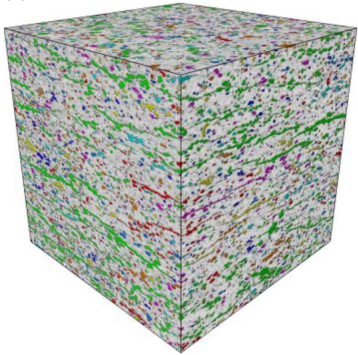

(d)

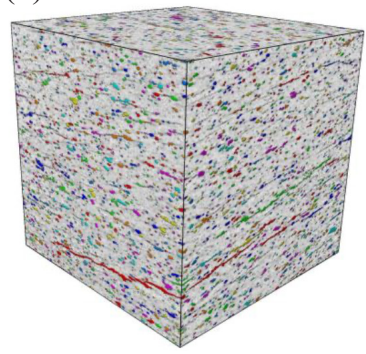

(g)

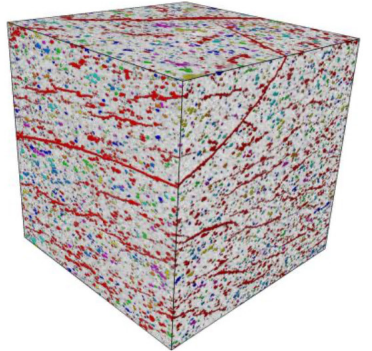

Fig. 5. Three-dimensional volume-rendering digital core of oil shale (the pore and fracture spaces are shown in different colours): (a) original sample $\left(25^{\circ} \mathrm{C}\right)$ (porosity $0.08 \%$ ); (b) $300{ }^{\circ} \mathrm{C}$ (porosity $0.2 \%$ ); (c) $350{ }^{\circ} \mathrm{C}$ (porosity $3.70 \%$ ); (d) $400{ }^{\circ} \mathrm{C}$ (porosity $8.18 \%$ ); (e) $450{ }^{\circ} \mathrm{C}$ (porosity $14.85 \%$ ); (f) $500{ }^{\circ} \mathrm{C}$ (porosity: $15.97 \%$ ); (g) $550{ }^{\circ} \mathrm{C}$ (porosity $16.73 \%$ ).

in the rock was more prominent. The pores and fractures of oil shale were extremely undeveloped at room temperature, and the porosity of the digital core was $0.08 \%$. When the temperature increased to $300{ }^{\circ} \mathrm{C}$, fractures began to sprout, and some pores were generated, but not obvious. The porosity of the digital core was $0.2 \%$. At $350{ }^{\circ} \mathrm{C}$, a few parallel fractures formed in oil shale, and the number of pores increased but was relatively dispersed. The porosity of the digital core was $3.70 \%$. With a continuous increase in the water vapour temperature, the scale and number of parallel fractures in oil shale increased. Fracture coalescence could be observed at $450{ }^{\circ} \mathrm{C}$ (Fig. 5e). When the temperature reached $550{ }^{\circ} \mathrm{C}$, the oil shale fractures developed 
significantly, and the opening of fractures increased (Fig. 5f). In addition to the connectivity of fractures in parallel bedding planes, the fracture surface perpendicular to the bedding direction appeared (Fig. $5 \mathrm{~g}$ ) and the porosity of digital cores reached $16.73 \%$.

The bedding plane fracture dominated the oil shale fractures at different temperatures, mainly due to oil shale being a sedimentary rock, and the bedding was relatively developed. Under the action of water vapour at different temperatures, the reaction of oil shale before $300{ }^{\circ} \mathrm{C}$ was the desorption of adsorbed water and part of interlayer water. After heating, the internal particle expansion of oil shale produced uneven deformation, and the bedding plane was the soft surface of the rock. Therefore, the thermal fracture along the bedding plane was more evident under the action of high-temperature water vapour. In the temperature range of $300^{\circ} \mathrm{C}-350^{\circ} \mathrm{C}$, the changes in the kerogen structure and volatilisation of a small amount of low boiling bitumen components were the main components in the Barkol oil shale. The crack formation was mainly affected by the impact of water vapour. When the temperature exceeded $350{ }^{\circ} \mathrm{C}$, with its further increase, the organic matter in oil shale began to pyrolyse. The pores began to form in the original distribution area of organic matter, and their number increased gradually. With the deepening of pyrolysis, the pores began to be connected. The secondary fractures began to form near the prominent fractures and gradually evolved to large-scale transverse and longitudinal staggered fractures.

\subsubsection{Pore size and volume distribution of oil shale at different temperatures}

Rock permeability is related to the pore structure and connectivity. In engineering applications, only interconnected pores and fractures can provide seepage channels for oil and gas products formed by pyrolysis and heating fluids. The microscopic pore structure of oil shale can be quantitatively analysed through the statistical analysis of pore size, pore number and volume. The size of the digital core was $1000^{3}$ pixels, and the pore group was equivalent to the sphere to calculate the corresponding pore size. Through a comparative analysis of the internal pore parameters of oil shale at different temperatures, the evolution characteristics of the pore structure can be obtained.

Figure 6 shows the pore size and volume distributions of oil shale samples at different temperatures. Quantity percentage reflects the contribution of the number of pores of different sizes to the total number of pores. Volume percentage reflects the contribution of the volume of pores of different sizes to the total volume of pores. The dash and solid lines in Figure 6(a), (c)-(h) represent the number and volume percentages of pores smaller than a specific size, respectively; the solid and broken lines in Figure 6(b), (i)-(n) represent the CPQ and CPV of pores smaller than a specific size, respectively. At $25^{\circ} \mathrm{C}$, the pore size in the digital core of oil shale was small, and the equivalent diameter of the maximum pore group was 12 pixels. The pore distribution was 
(a)

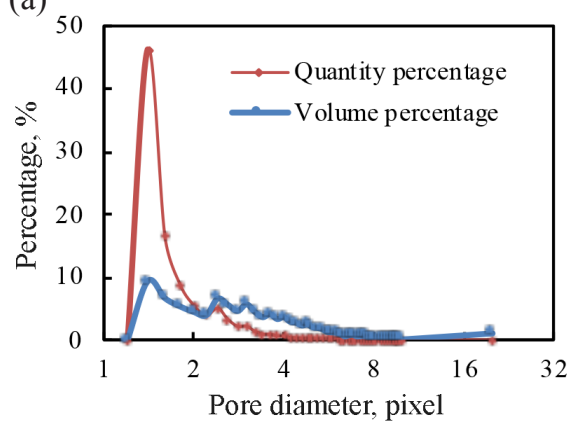

Original sample $\left(25^{\circ} \mathrm{C}\right)$

(c)

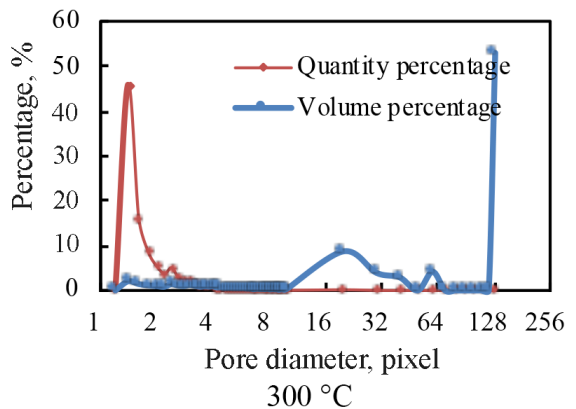

(d)

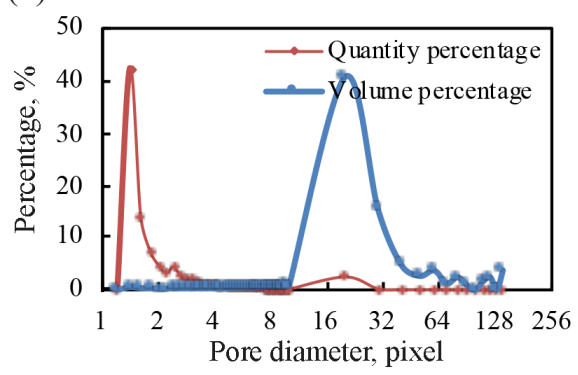

$350{ }^{\circ} \mathrm{C}$

(e)

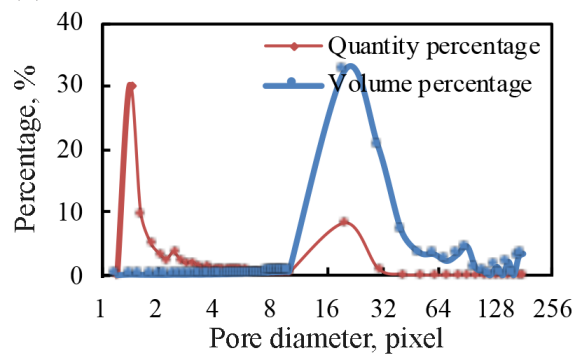

$400{ }^{\circ} \mathrm{C}$ (b)

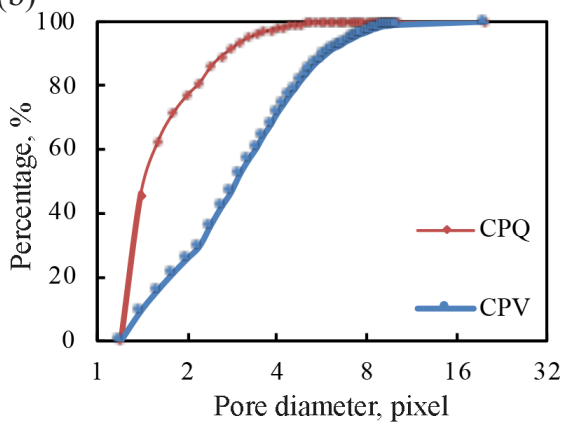

Original sample $\left(25^{\circ} \mathrm{C}\right)$

(i)

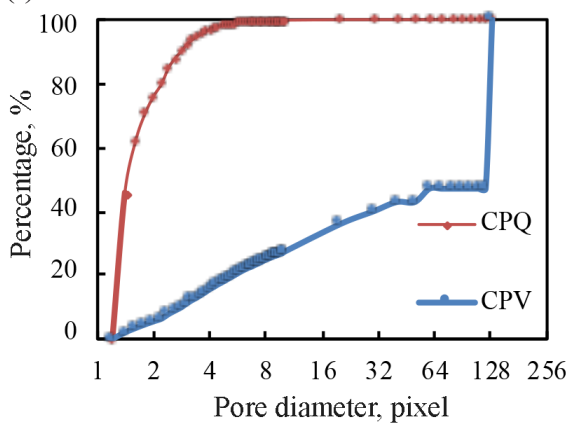
$300{ }^{\circ} \mathrm{C}$

(j)

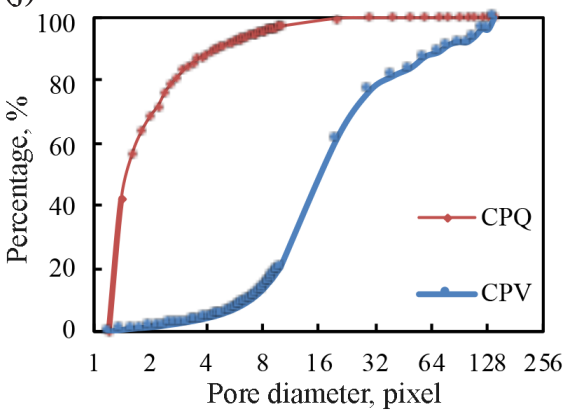

$350^{\circ} \mathrm{C}$

(k)

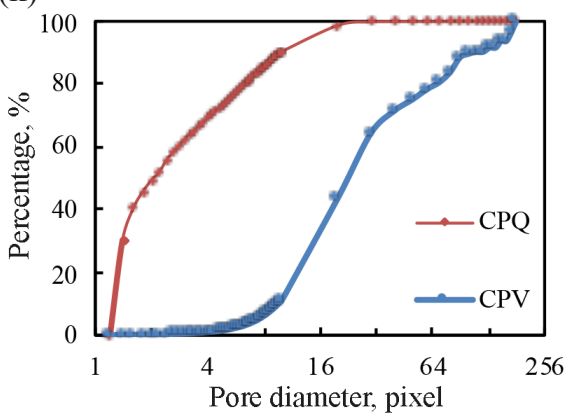

$400{ }^{\circ} \mathrm{C}$ 
(f)

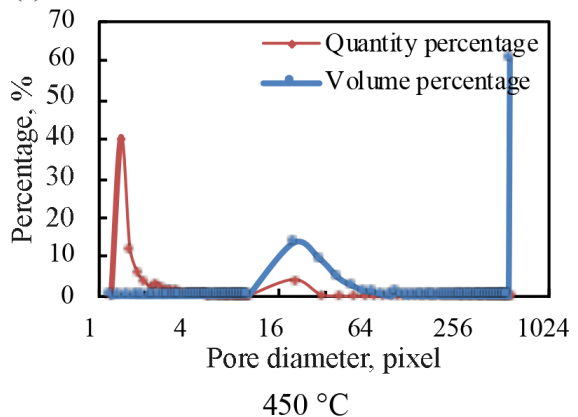

(g)

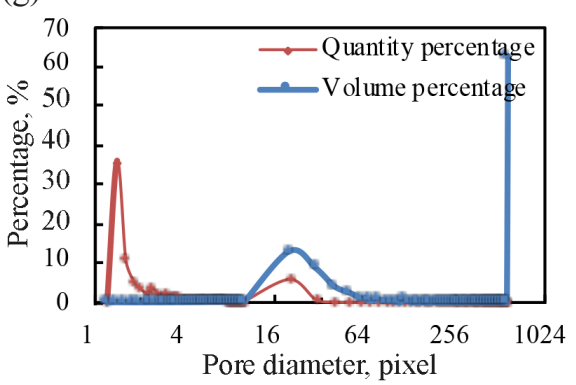

$500{ }^{\circ} \mathrm{C}$

(h)

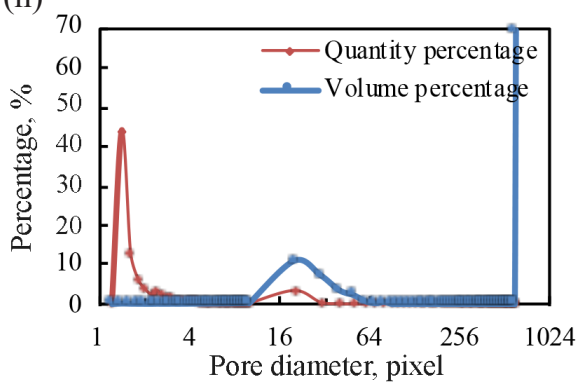

$550{ }^{\circ} \mathrm{C}$
(1)

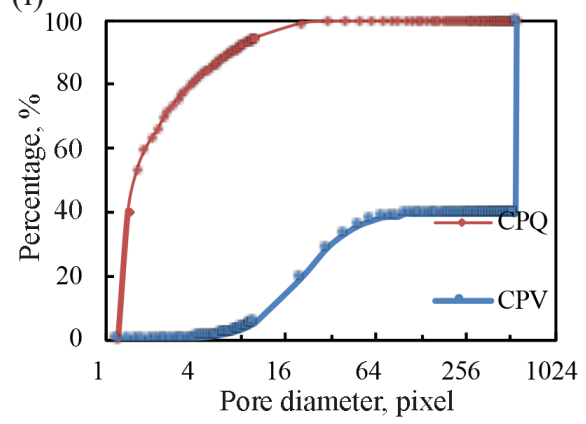

$450{ }^{\circ} \mathrm{C}$

(m)

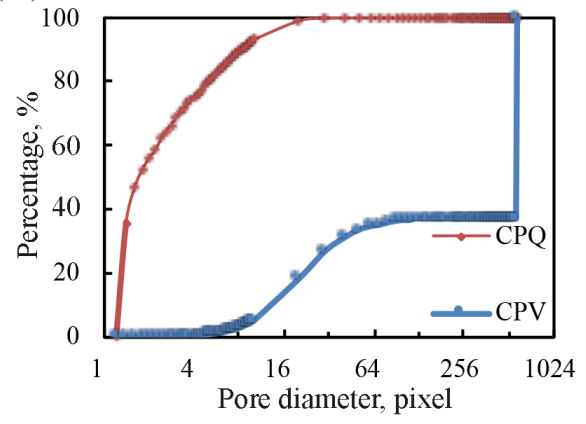

$500^{\circ} \mathrm{C}$

(n)

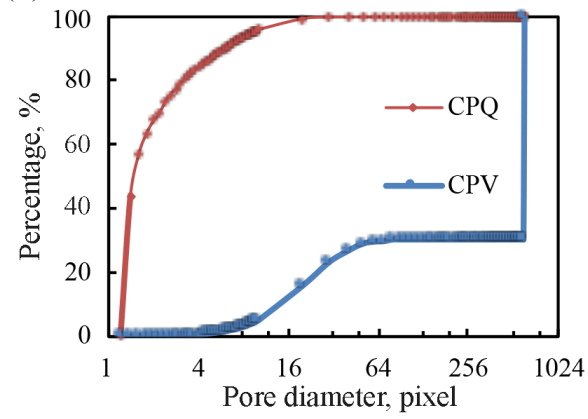

$550{ }^{\circ} \mathrm{C}$

Fig. 6. Pore size and volume distributions of oil shale samples at different temperatures: (a) original sample at $25{ }^{\circ} \mathrm{C}$; (b) original sample at $25{ }^{\circ} \mathrm{C}$; (c)-(h) samples with the number and volume percentages of pores smaller than a specific size; (i)-(n) samples with the cumulative percentage of quantity (CPQ) and volume (CPV) of pores smaller than a specific size. 
the most abundant between 1.2 and 4 pixels, accounting for $97.99 \%$ of the total number of pores, and the volume ratio was $71.17 \%$. After water vapour pyrolysis at $300{ }^{\circ} \mathrm{C}$, the pores in each pore size stage changed. The number distribution of pores with diameters in the range of 1.2-4 pixels accounted for $96.95 \%$ of the total pores, similar to that at $25{ }^{\circ} \mathrm{C}$. However, the pore volume in this pore size stage accounted for only $15.6 \%$ of the total pore volume, contributing little to the total pore space. There were two peaks in the pore volume percentage curve, which were in the ranges of 10-60 and 126-128 pixels, respectively; their volume contribution rates were $19.76 \%$ and $52.94 \%$, respectively. At $350{ }^{\circ} \mathrm{C}$, the number and volume of pores with equivalent pore sizes in the range of 10-30 pixels showed an increasing trend. At this temperature, the pore volume with an equivalent pore size within $10-140$ pixels in oil shale contributed the most, accounting for $79.45 \%$ of the total pore volume. When the temperature increased from $350{ }^{\circ} \mathrm{C}$ to $400{ }^{\circ} \mathrm{C}$, the pore volume with an equivalent diameter more than 10 pixels in oil shale increased, accounting for $88.91 \%$ of the total pore volume. With a continuous increase in water vapour temperature, the organic matter in oil shale began undergoing large-scale pyrolysis, and the curves at $450{ }^{\circ} \mathrm{C}, 500{ }^{\circ} \mathrm{C}$ and $550{ }^{\circ} \mathrm{C}$ showed the same trend. New pores were formed and gradually connected in oil shale. The number distribution was dominated by pores with an equivalent diameter in the range of $1.2-4$ pixels, accounting for $81.60 \%, 75.48 \%$ and $84.28 \%$ of the total pores, respectively. The maximum pore group contributed the most to the pore volume.

To facilitate the comparative analysis, the pore groups were divided into five groups with apertures of 50,100, 500 and $1000 \mu \mathrm{m}$ as the boundaries. The statistical results are given in Tables 2 and 3.

Table. 2. Volume percentage of pores with different diameters in digital cores, $\%$

\begin{tabular}{|c|c|c|c|c|c|}
\hline \multirow{2}{*}{$\begin{array}{c}\text { Temperature, } \\
{ }^{\circ} \mathrm{C}\end{array}$} & \multicolumn{5}{|c|}{ Pore diameter, $\mu \mathrm{m}$} \\
\cline { 2 - 6 } & $\mathrm{d}<50$ & $50<\mathrm{d}<100$ & $100<\mathrm{d}<500$ & $500<\mathrm{d}<1000$ & $\mathrm{~d}>1000$ \\
\hline $\begin{array}{c}\text { Original sample } \\
\left(25^{\circ} \mathrm{C}\right)\end{array}$ & 0.064 & 0.01 & 0.001 & 0 & 0 \\
300 & 0.039 & 0.016 & 0.03 & 0.009 & 0.106 \\
350 & 0.235 & 0.604 & 2.318 & 0.256 & 0.289 \\
400 & 0.154 & 0.879 & 5.197 & 1.151 & 0.795 \\
450 & 0.191 & 0.732 & 4.456 & 0.494 & 8.978 \\
500 & 0.167 & 0.759 & 4.476 & 0.458 & 10.112 \\
550 & 0.205 & 0.716 & 3.96 & 0.192 & 11.651 \\
\hline
\end{tabular}


Table. 3. Volume percentage of pores with different diameters in total pore space, $\%$

\begin{tabular}{|c|c|c|c|c|c|}
\hline \multirow{2}{*}{$\begin{array}{c}\text { Temperature, } \\
{ }^{\circ} \mathrm{C}\end{array}$} & \multicolumn{5}{|c|}{ Pore diameter, $\mu \mathrm{m}$} \\
\cline { 2 - 6 } & $\mathrm{d}<50$ & $50<\mathrm{d}<100$ & $100<\mathrm{d}<500$ & $500<\mathrm{d}<1000$ & $\mathrm{~d}>1000$ \\
\hline $\begin{array}{c}\text { Original sample } \\
\left(25^{\circ} \mathrm{C}\right)\end{array}$ & 85.9 & 13.37 & 0.73 & 0 & 0 \\
300 & 19.57 & 8.21 & 15.1 & 4.18 & 52.94 \\
350 & 6.34 & 16.32 & 62.61 & 6.93 & 7.8 \\
400 & 1.88 & 10.75 & 63.56 & 14.08 & 9.73 \\
450 & 1.29 & 4.93 & 30 & 3.33 & 60.45 \\
500 & 1.05 & 4.75 & 28.02 & 2.87 & 63.31 \\
550 & 1.23 & 4.29 & 23.68 & 1.15 & 69.65 \\
\hline
\end{tabular}

Figure 7 shows the maximum pore group distribution of oil shale at different temperatures. At $25^{\circ} \mathrm{C}$, the pore distribution within the digital core was less than $50 \mu \mathrm{m}$, accounting for $85.9 \%$ of the total pore volume. After water vapour pyrolysis at $300{ }^{\circ} \mathrm{C}$, the pores in each pore size stage changed. According to the results of the TG experiment, the weight loss of oil shale was small before $300{ }^{\circ} \mathrm{C}$ and the reaction was mainly water precipitation. The thermal fracture led to the formation of pores and fissures in the bedding plane direction of oil shale. The maximum pore group was distributed along the bedding plane (Fig. 7b), and the diameter was $1201.73 \mu \mathrm{m}$. The maximum pore group volume accounted for $52.94 \%$ of the total pore volume. At $350{ }^{\circ} \mathrm{C}$, the pore volume of oil shale at all levels showed an increasing trend, and the maximum pore group began to connect and increase toward the vertical bedding. The pore distribution in oil shale was mainly in the range of $100-500 \mu \mathrm{m}$, accounting for $62.61 \%$ of the total pore volume. When the temperature increased from $350{ }^{\circ} \mathrm{C}$ to $400{ }^{\circ} \mathrm{C}$, the pore volume of each stage, except that greater than $50 \mu \mathrm{m}$, increased, indicating that at this stage, with the progress of pyrolysis, the pore volume of oil shale increased, and pores with small pore sizes gradually connected. At this stage, the pore distribution in oil shale was dominated by pores with diameters in the range of 100-500 $\mu \mathrm{m}$, accounting for $63.56 \%$ of the total pore volume. When the steam temperature exceeded 400 ${ }^{\circ} \mathrm{C}$, the volume pores smaller than $1000 \mu \mathrm{m}$ in oil shale decreased, indicating that with the continuous pyrolysis of organic matter, the pores in oil shale were gradually connected. At $400{ }^{\circ} \mathrm{C}$, the seepage channel connecting the entire digital core area was formed, and the scale gradually increased with an increase in temperature. At $550{ }^{\circ} \mathrm{C}$, the diameter of the maximum pore mass was $5756.72 \mathrm{~m}$, accounting for $69.65 \%$ of the total pore volume. 
(a)

(b)

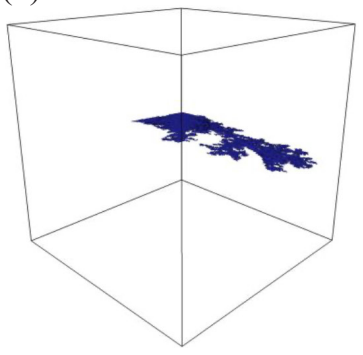

(e)

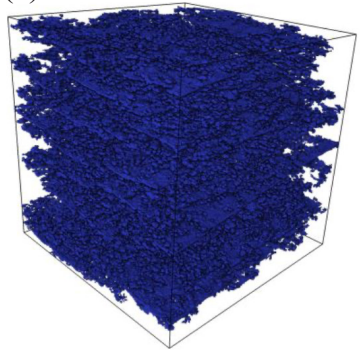

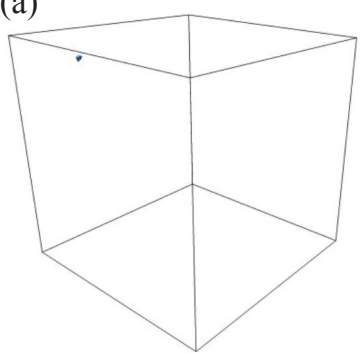

(c)

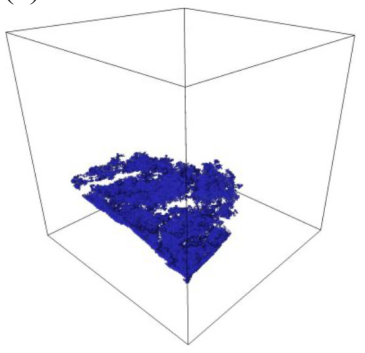

(f)

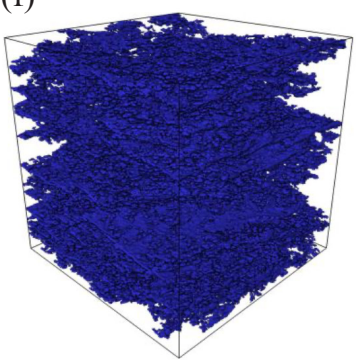

(d)

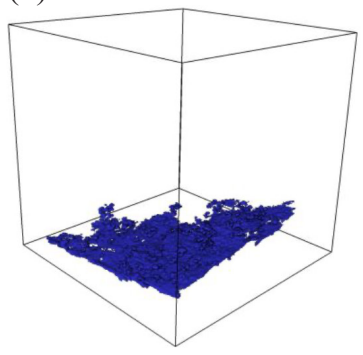

(g)

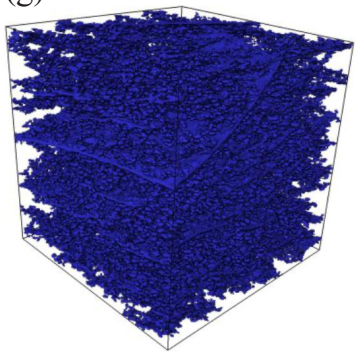

Fig. 7. Maximum pore group distribution of oil shale at different temperatures: (a) original sample $\left(25^{\circ} \mathrm{C}\right.$ ); (b) $300{ }^{\circ} \mathrm{C}$; (c) $350{ }^{\circ} \mathrm{C}$; (d) $400{ }^{\circ} \mathrm{C}$; (e) $450{ }^{\circ} \mathrm{C}$; (f) $500{ }^{\circ} \mathrm{C}$; (g) $550{ }^{\circ} \mathrm{C}$.

The original oil shale was relatively dense, and pores and fractures were undeveloped. When the water vapour temperature was $300{ }^{\circ} \mathrm{C}$, owing to the influence of thermal rupture, cracks expanded along the weak bedding plane and formed pore connectivity groups in oil shale. With increasing water vapour temperature, the organic matter components in oil shale began to decompose according to different boiling points. Several pore structures opened up in the space occupied by the original organic matter. These pores were gradually connected with adjacent cracks so that the maximum pore group of oil shale extended along the direction perpendicular to the bedding plane. The apparent thermal cracking and pyrolysis occurred under high-temperature water vapour, which resulted in pore and fracture structure development in the rock mass. Moreover, the porefracture structure inside the rock mass provided a good channel for the seepage and heat transfer of high-temperature fluid and the migration of pyrolysis products. 


\section{Conclusions}

In this paper, a self-designed test system for injecting water vapour was used to pyrolyse oil shale from Barkol, Xinjiang, China. The internal structure of oil shale samples after water vapour pyrolysis at different temperatures was characterised by micro-computed tomography. The main conclusions are as follows:

1. After high-temperature water vapour pyrolysis, many pores and fractures were generated in oil shale, and the porosity increased from $0.08 \%$ of the original state to $16.73 \%$ at $550{ }^{\circ} \mathrm{C}$. In the oil shale samples at different temperatures, the pores with equivalent diameters in the range of 1.2-4 pixels were the most widely distributed, accounting for more than $70 \%$ of the total pores. However, the contribution to the total pore volume was small. This part of pores had little effect on the migration of oil shale pyrolysis products.

2. After high-temperature water vapour pyrolysis, the equivalent diameter of the maximum pore group formed in oil shale reached the mm level. With an increase in the water vapour temperature, the pores and fissures in oil shale were continuously generated and gradually connected. At $450{ }^{\circ} \mathrm{C}$, the seepage channel connecting the entire digital core area was formed. At $550{ }^{\circ} \mathrm{C}$, the equivalent diameter of the maximum pore group reached $5756.72 \mu \mathrm{m}$, accounting for $69.65 \%$ of the total pore volume.

3 . Under the action of high-temperature water vapour, evident thermal cracking and pyrolysis occurred in oil shale and fractures developed along the weak bedding plane. The number and scale of fractures gradually increased and connected. The pores generated by the pyrolysis of organic matter gradually connected with adjacent fractures, making the maximum pore group of oil shale expand along the direction perpendicular to the bedding plane.

\section{Acknowledgments}

This work was supported by the National Natural Science Foundation of China (51704206), National Key R\&D Program of China (2019YFA0705501) and the Foundation of Shanxi Institute of Energy (ZZ-2018103).

\section{REFERENCES}

1. Demirbas, A., Alidrisi, H., Balubaid, M. A. API gravity, sulfur content, and desulfurization of crude oil. Petrol. Sci. Technol., 2015, 33(1), 93-101.

2. Washburn, K. E., Birdwell, J. E., Foster, M., Gutierrez, F. Detailed description of oil shale organic and mineralogical heterogeneity via Fourier transform infrared microscopy. Energy Fuels, 2015, 29(7), 4264-4271. 
3. Dyni, J. R. Geology and resources of some world oil-shale deposits. Oil Shale, 2003, 20(3), 193-252.

4. Al-Ayed, O. S., Suliman, M. R., Rahman, N. A. Kinetic modeling of liquid generation from oil shale in fixed bed retort. Appl. Energy, 2010, 87(7), 2273-2277.

5. Tong, J. H., Jiang, X. M., Han, X. X., Wang, X. Y. Evaluation of the macromolecular structure of Huadian oil shale kerogen using molecular modeling. Fuel, 2016, 181, 330-339.

6. Niu, M. T., Wang, S., Han, X. X., Jiang, X. M. Yield and characteristics of shale oil from the retorting of oil shale and fine oil-shale ash mixtures. Appl. Energy, 2013, 111, 234-239.

7. Demirbas, A. Conversion of oil shale to liquid hydrocarbons. Energ. Source. Part A, 2016, 38(18), 2698-2703.

8. Liu, Z. J., Meng, Q. T., Dong, Q. S., Zhu, J. W., Guo, W., Ye, S. Q., Liu, R., Jia, J. L. Characteristics and resource potential of oil shale in China. Oil Shale, 2017, 34(1), 15-41.

9. Liu, Z. J., Dong, Q. S., Ye, S. Q., Zhu, J. W., Guo, W., Li, D. C., Liu, R., Zhang, H. L., Du, J. F. The situation of oil shale resources in China. Journal of Jilin University (Earth Science Edition), 2006, 36(6), 869-876 (in Chinese).

10. Deng, S. H., Wang, Z. J., Gu, Q., Meng, F. Y., Li, J. F., Wang, H. Y. Extracting hydrocarbons from Huadian oil shale by sub-critical water. Fuel Process. Technol., 2011, 92(5), 1062-1067.

11. Selberg, A., Viik, M., Pall, P., Tenno, T. Environmental impact of closing of oil shale mines on river water quality in North-Eastern Estonia. Oil Shale, 2009, 26(2), 169-183.

12. Tohver, T. Utilization of waste rock from oil shale mining. Oil Shale, 2010, 27(4), 321-330.

13. Sun, Y. H., Guo, W., Deng, S. H. The status and development trend of insitu conversion and drilling exploitation technology for oil shale. Drilling Engineering, 2021, 48(01), 57-67 (in Chinese).

14. Kang, Z. Q., Zhao, Y. S., Yang, D., Tian, L. J., Li, X. A pilot investigation of pyrolysis from oil and gas extraction from oil shale by in-situ superheated steam injection. J. Petrol. Sci. Eng., 2020, 186, 106785.

15. Sun, Y. H., Kang, S. J., Wang, S. Y., He, L., Guo, W., Li, Q., Deng, S. H. Subcritical water extraction of Huadian oil shale at $300{ }^{\circ} \mathrm{C}$. Energy Fuels, 2019, 33(3), 2106-2114.

16. Lei, J., Pan, B. Z., Guo, Y. H., Fan, Y. F., Xue, L. F., Deng, S. H., Zhang, L. H., Ruhan, A. A comprehensive analysis of the pyrolysis effects on oil shale pore structures at multiscale using different measurement methods. Energy, 2021, 227, 120359.

17. Saif, T., Lin, Q. Y., Singh, K., Bijeljic, B., Blunt, M. J. Dynamic imaging of oil shale pyrolysis using synchrotron x-ray microtomography. Geophys. Res. Lett., 2016, 43(13), 6799-6807. 
18. Zhao, J. P., Dong, X., Zhang, J. Y., Chen, H., Zhang, W. J. A 3D FIB-SEM technique for quantitative characterization of oil shale's microstructure: A case study from the Shahejie Formation in Dongying Depression, China. Energy Sci. Eng., 2021, 9(1), 116-128.

19. Li, G. Y., Ma, Z. L., Zheng, J. X., Bao, F., Zheng, L. J. NMR analysis of the physical change of oil shales during in situ pyrolysis at different temperatures. Petroleum Geology and Experiment, 2016, 38(3), 402-406 (in Chinese).

20. Yang, L. S., Yang, D., Zhao, J., Liu, Z. H., Kang, Z. Q. Changes of oil shale pore structure and permeability at different temperatures. Oil Shale, 2016, 33(2), $101-110$.

21. Mozaffari, S., Järvik, O., Baird, Z. S. Effect of $\mathrm{N}_{2}$ and $\mathrm{CO}_{2}$ on shale oil from pyrolysis of Estonian oil shale. International Journal of Coal Preparation and Utilization, 2021. https://doi.org/10.1080/19392699.2021.1914025

22. Yang, D., Wang, L., Zhao, Y. S., Kang, Z. Q. Investigating pilot test of oil shale pyrolysis and oil and gas upgrading by water vapor injection. J. Petrol. Sci. Eng., 2021, 196, 108101.

23. Zhang, M. Q., Liu, Z. J., Sun, P. C., Wang, J. X., Li, Y. J., Hou, L. Y. Well logging identification of Lower Jurassic Badaowan Formation oil shale in Dachanggou Basin, Xinjiang. Coal Geology of China, 2020, 32(6), 27-35 (in Chinese).

24. Wang, J. X., Sun, P. C., Liu, Z. J., Li, Y. J. Characteristics and genesis of lacustrine laminar coal and oil shale: A case study in the Dachanggou Basin, Xinjiang, Northwest China. Mar. Petrol. Geol., 2021, 126, 104924. 